\title{
Evaluation of minor pathogen intramammary infection, susceptibility parameters, and somatic cell counts on the development of new intramammary infections with major mastitis pathogens
}

\author{
K. K. Reyher, ${ }^{\star} \dagger^{1}$ I. R. Dohoo, ${ }^{\star} \dagger$ D. T. Scholl, ${ }^{\star} \ddagger$ and G. P. Keefe ${ }^{\star} \dagger$ \\ ${ }^{*}$ Canadian Bovine Mastitis Research Network, C.P. 5000, St-Hyacinthe, Québec, J2S 7C6, Canada \\ †Centre for Veterinary Epidemiological Research, University of Prince Edward Island, Charlottetown, PEI, C1A 3M6, Canada \\ $\ddagger$ Agricultural Experiment Station, Box 2207, South Dakota State University, Brookings, SD 57007
}

\begin{abstract}
Major mastitis pathogens such as Staphylococcus aureus, Streptococcus uberis, Streptococcus dysgalactiae, and coliforms are usually considered more virulent and damaging to the udder than minor mastitis pathogens such as Corynebacterium spp. and coagulase-negative staphylococci (CNS). The current literature comprises several studies $(\mathrm{n}=38)$ detailing analyses with conflicting results as to whether intramammary infections (IMI) with the minor pathogens decrease, increase, or have no effect on the risk of a quarter acquiring a new IMI (NIMI) with a major pathogen. The Canadian Bovine Mastitis Research Network has a large mastitis database derived from a 2-yr data collection on a national cohort of dairy farms, and data from this initiative were used to further investigate the effect of IMI with minor pathogens on the acquisition of new major pathogen infections (defined as a culture-positive quarter sample in a quarter that had been free of that major pathogen in previous samples in the sampling period). Longitudinal milk samplings of clinically normal udders taken over several 6-wk periods as well as samples from cows pre-dry-off and postcalving were used to this end ( $\mathrm{n}=$ 80,397 quarter milk samples). The effects of CNS and Corynebacterium spp. on the major mastitis pathogens Staph. aureus, Strep. uberis, Strep. dysgalactiae, and coliform bacteria (Escherichia coli and Klebsiella spp.) were investigated using risk ratio analyses and multilevel logistic regression models. Quarter-, cow- and herd-level susceptibility parameters were also evaluated and were able to account for the increased susceptibility that exists within herds, cows and quarters, removing it from estimates for the effects of the minor pathogens. Increased quarter-level susceptibility was associated with increased risk of major pathogen NIMI for all pathogens except the coliforms. Increased somatic cell
\end{abstract}

Received November 14, 2011

Accepted February 23, 2012.

${ }^{1}$ Corresponding author: kreyher@upei.ca count was consistently associated with elevated risk of new major pathogen infections, but this was assumed to be a result of low sensitivity of bacteriology to diagnose major pathogen NIMI expediently and accurately. The presence of CNS in the sample 2 samplings before the occurrence of a NIMI increased the odds of experiencing a Staph. aureus NIMI 2.0 times, making the presence of CNS a risk factor for acquiring a Staph. aureus NIMI. Even with this extensive data set, power was insufficient to make a definitive statement about the effect of minor pathogen IMI on the acquisition of major pathogen NIMI. Definitively answering questions of this nature are likely to require an extremely large data set dedicated particularly to minor pathogen presence and NIMI with major pathogens.

Key words: major pathogens, minor pathogens, protective effect, risk factor

\section{INTRODUCTION}

Major mastitis pathogens such as Staphylococcus aureus, Streptococcus uberis, Streptococcus dysgalactiae, and coliforms often cause clinical mastitis episodes, resulting in damage to the bovine udder, along with substantial inflammation, detectable by an increase in SCC. Major pathogens often persist in the udder for an extended period of time and may require prolonged antimicrobial therapy. Conversely, minor mastitis pathogens such as Corynebacterium spp. and CNS usually cause much less severe reactions. At present, CNS are the most prevalent group of bacteria isolated from bovine milk in several countries (Pyörälä and Taponen, 2009; Reyher et al., 2011). Mastitis caused by CNS is typically a mild, subclinical reaction (Schukken et al., 2009) that is most commonly associated with increased milk SCC. Coagulase-negative staphylococci IMI have been associated both with decreased milk production (Green et al., 2006) and with slight but significant increased production (Compton et al., 2007; Schukken et al., 2009; Piepers et al., 2010). Similarly, infection 
with Corynebacterium spp. causes a moderate increase in SCC with minimal to no milk production loss.

Several studies investigating the effects of minor pathogens on the risk of acquisition of major pathogen infections have yielded contradictory results [Pyörälä and Taponen, 2009; K. K. Reyher, I. R. Dohoo, C. W. Revie (Canadian Bovine Mastitis Research Network, St-Hyacinthe, Québec, Canada, and Centre for Veterinary Epidemiological Research, University of Prince Edward Island, Charlottetown, PEI, Canada), and D. Haine (Canadian Bovine Mastitis Research Network, St-Hyacinthe, Québec, Canada, and Département de pathologie et microbiologie, Faculté de médecine vétérinaire, Université de Montréal, St-Hyacinthe, Québec, Canada); unpublished data]. Seventeen papers detailing experimental challenge studies were identified in the published literature. These involved inoculation of quarters with both minor and major pathogens, or natural infections with minor pathogens and experimentally induced infections with major pathogens. Infections were introduced either by intracisternal infusion, teat-end exposure or inoculation into the teat canal. Twenty-four of the analyses presented in these papers showed minor pathogens to have a protective effect on quarters, although only 17 yielded statistically significant $(P \leq 0.05)$ results. Six of the analyses described showed an increased risk for major pathogen infections, only 2 of which were statistically significant. Also, another 6 analyses stated that no difference in the major pathogen infections in quarters infected or uninfected with minor pathogens could be shown. The experimental literature, therefore, seems to present a predilection for protection by the minor pathogens. Twenty-one observational studies assessing naturally occurring IMI, which specifically addressed interactions between major and minor pathogens, were identified. Of these, 29 analyses (23 of which had statistically significant results) showed a protective effect of minor pathogens, and 28 revealed increased risk (16 with statistical significance). Twelve analyses failed to find any effect. The observational literature, therefore, illustrates a more divided view about the effects of the minor pathogens (K. K. Reyher, I. R. Dohoo, C. W. Revie, and D. Haine, unpublished data).

Even if the published literature were to give more uniform results, certain shortcomings of publications on this topic are recognized. Lam et al. (1997) pointed out that only a few strains of pathogens have been tested in laboratory settings, although a large number exist in nature. Also, one of the roles of minor pathogens may be to prevent entry of major pathogens into the mammary gland, a situation which is certainly overcome by direct injection of pathogens into the teat canal or cistern. The definition of an IMI also provides some difficulties, as even mastitis experts disagree on how infection is defined (Andersen et al., 2010). In the 38 papers reviewed, 8 gave no information about how IMI was defined, and among the others, 22 differing definitions of IMI were given. As if this were not challenge enough, time between samplings of mammary quarters in these studies ranged from every 10 min to 2 samplings separated by at least 9 mo. Although several mastitis pathogens may cause chronic infection, others are more transient and may be missed by long intervals between samplings.

Data collected longitudinally are best suited to give indications of causal relationships within a biological system. Even with longitudinal data, however, a certain number of infections are required to achieve the power to find significant relationships. Among the studies surveyed, between 9 and 1,450 cows were included, and these originated in 1 to 74 herds. Numbers of infections also varied widely, from 2 to 1,777 infections with minor pathogens and 4 to 322 infections with major pathogens. Several types of analyses also exist to examine this vast array of data; 14 methods of analysis were identified in these 38 papers. Few of these accounted for within-herd, within-cow, or within-quarter factors, which undoubtedly play a role in the response to mastitis pathogens. Green et al. (2002) identified several issues relating to quarter susceptibility: anatomical features, immunological characteristics, previous infections, and other alterations in the environment. All of these factors may affect the defense of a quarter, and even of a cow, to pathogen challenge. Cow-level factors such as breed, season of calving, age, and stage of lactation may have an effect, and herd-level factors such as overall pathogen profile undoubtedly play a role. Analyses that fail to take into account these factors certainly leave themselves open to a great number of confounding factors.

A recent publication has set forth the sensitivity (Se) and specificity $(\mathbf{S p})$ of several IMI definitions from a single milk sample (Dohoo et al., 2011b), and provides guidance into the situations where definitions should be used to maximize the parameters necessary to achieve specific research goals. A large amount of data has also been amassed by the Canadian Bovine Mastitis Research Network (CBMRN; Reyher et al., 2011), with frequent observations of mammary quarters allowing clarity of the presence of minor pathogen infections with respect to acquisition of major pathogen infections, along with statistical power to detect effects of pathogen interactions while accounting for herd, cow, and quarter susceptibility factors. It is the objective of this paper, therefore, to provide further insight into the effect of naturally occurring infections with minor mastitis pathogens (namely Corynebacterium spp. and 
CNS) on the acquisition of new IMI (NIMI) with the major mastitis pathogens Staph. aureus, Strep. uberis, Strep. dysgalactiae, and coliforms (Escherichia coli and Klebsiella spp.). Susceptibility parameters for herdlevel, cow-level and quarter-level susceptibility are also evaluated, as is the association between SCC and the acquisition of major pathogen NIMI.

\section{MATERIALS AND METHODS}

\section{Sample Collection}

All samples were taken as part of the CBMRN's large data collection platform, the National Cohort of Dairy Farms (Reyher et al., 2011). Longitudinal quarter milk samples were collected from lactating cows that were considered clinically normal (no abnormal milk). Fifteen cows per period (10 randomly selected midlactation cows and the 5 most recently calved cows in the herd) were enrolled for each of 4 sampling periods spanning 2 yr. Sampling periods consisting of 3 visits separated by intervals of $3 \mathrm{wk}$ were independently performed during the winters of 2007 and 2008 as well as the summer of 2008. An intensive sampling period consisting of 7 weekly samplings occurred during the summer of 2007. Samples were also collected from 15 cows each year between 4 and 2 wk before dry-off and between 2 wk and dry-off (both considered pre-dry-off samples), as well as within $24 \mathrm{~h}$ of calving and from 1 to 2 wk after calving (postcalving samples). Most cows in this cohort were treated with antibiotic dry cow therapy at the time of dry-off.

\section{Bacteriological Culture}

Milk samples were frozen and submitted to one of the bacteriology laboratories comprising the CBMRN Mastitis Laboratory Network. Laboratories followed standardized protocols based on National Mastitis Council (NMC) guidelines for bacteriological culture and species identification (Hogan et al., 1999). A milk sample from which 3 or more different species were cultured was considered contaminated, although Staph. aureus and Streptococcus agalactiae identified in these samples were enumerated.

\section{Definitions}

IMI Definition. Samples were considered to have an IMI with any of the major pathogens or with $\mathrm{Co}^{-}$ rynebacterium spp. if they cultured 100 or more cfu/ $\mathrm{mL}$ of the organism of interest in either a pure or mixed growth. Samples were considered to have an IMI caused by CNS if they cultured 200 or more $\mathrm{cfu} / \mathrm{mL}$ in either pure or mixed growth. The IMI definitions were chosen to balance the Se and Sp of new IMI diagnoses, based on the definitions presented by Dohoo et al. (2011b). In this analysis, a stricter definition for IMI caused by CNS was used to maximize specificity of exposure. Single samples were used; previous studies have shown that single samples are often in agreement for contagious organisms (Erskine and Eberhart, 1988) and that the Se of a single sample is better than that of duplicate samples interpreted in series and comparable to that of triplicate samples with only a marginal loss in specificity (Dohoo et al., 2011a).

NIMI Definition. For the risk calculations, a NIMI was defined as a quarter without IMI initially, but with IMI at the next subsequent sampling (usually 2 wk later for pre-dry-off and postcalving samples; $3 \mathrm{wk}$ later for lactational samples taken during the winters of 2007 and 2008, and the summer of 2008; and 1 wk later for lactational samples taken during the summer of 2007). In the multilevel logistic models, a quarter was identified with a NIMI if a positive sample for the pathogen of interest followed at least 1 negative sample. For the multilevel logistic analyses, only the first NIMI within a sampling period (e.g., winter 2007) was included in the analyses; for instance, if a quarter cultured negative in a first sample and positive in the subsequent sample, no other records from that quarter in that sampling period were considered. This was done to limit the number of false NIMI diagnoses that might occur if the pathogen of interest was missed on a subsequent sampling later in that sampling period (a function of low Se), although the quarter might still be infected.

For the multilevel logistic regression analyses, data were collapsed to the quarter level by choosing each sample with a NIMI along with a randomly chosen sample for each quarter in a sampling period lacking a NIMI with the selected organism.

Samplings Considered. For the multilevel logistic regression analyses, the presence or absence of a minor pathogen IMI at 2 time points was considered: once at the sampling immediately before acquisition of a major pathogen NIMI, and also at the sampling 2 before acquisition of a major pathogen NIMI. The natural logarithm transformation of the SCC (lnSCC) was also considered at each of these 2 prior samplings.

Susceptibility Parameters. To model the effect of susceptibility to infection separately from the effect of the presence of a minor pathogen in an individual quarter during a sampling period before the development of a NIMI, the proportions of samples of the same quarter, cow, or herd that were infected with any of the 7 previously mentioned pathogens of interest were used as an estimation of susceptibility to infection (be it with major or minor pathogens, except 
the major pathogen of interest). Infections with Enterococcus spp. were also included in this measure of susceptibility, as the presence of this group of pathogens was considered relevant, although they were not included as major or minor pathogens. Proportions of infections at the quarter, cow, and herd levels (each to account for its pertinent level of susceptibility) were calculated, and the proportions before and after the occurrence of a NIMI were compared. No difference was observed in the proportion of infections before and after a NIMI in the Staph. aureus or coliform data. The occurrence of a Strep. uberis NIMI, however, seemed to be associated with a lower proportion of infections with other organisms at the quarter level after the NIMI, and the occurrence of a Strep. dysgalactiae NIMI seemed to be associated with an increase in the proportion of infections with other organisms after the NIMI. To estimate the susceptibility measure as precisely as possible, all of the data (samples taken before and after a NIMI occurred) were used in calculations of the proportions.

\section{Statistical Analysis}

Risk Ratios. The risk of a quarter acquiring a NIMI with any of the major pathogens (Staph. aureus, Strep. uberis, Strep. dysgalactiae, and the coliforms, E. coli and Klebsiella spp.), given that it was previously infected with either of the 2 minor pathogens (CNS and Corynebacterium spp.), was calculated and compared with the risk of the same quarter becoming infected without infection with either of the 2 minor pathogens. The null hypothesis was that this risk ratio would equal 1.0 , and testing using a $\chi^{2}$ statistic was carried out. Calculation of risk ratios allowed for use of all the longitudinal data as well as direct comparability with the previously published literature.

Multilevel Logistic Regression. Multilevel logistic models using NIMI with a specific major pathogen as an outcome were run, which included the following predictors: lactation number; DIM at the time of sampling; sampling period (e.g., winter 2007); herd-, cow-, and quarter-level susceptibility parameters; $\operatorname{lnSCC}$ in each of the 2 samples previous to the NIMI; CNS infection in each of the 2 samples before the NIMI; and Corynebacterium spp. infection in each of the 2 samples before the NIMI. Random effects were added at the herd level to account for clustering of cows within herds and at the cow level to account for clustering of quarters within cows. Repeated sampling of cows during more than 1 sampling period occurred infrequently, so repeated measures were not included in the analyses. Intraclass correlation coefficients (ICC) were calculated using the latent variable approximation to estimate the degree of clustering within herds and cows (Dohoo et al., 2009). Models for each major organism (Staph aureus, Strep. uberis, Strep. dysgalactiae, and the coliforms) were evaluated. A dose effect for the amount of CNS cultured was also explored using the number of cfu cultured as a categorical predictor. Analyses were done using Stata/ IC 11.0 (StataCorp LP, College Station, TX).

\section{RESULTS}

\section{Risk Ratios}

The data used for the risk ratio analyses is illustrated in Figure 1. These analyses began with 19,415 samples from cows pre-dry-off and 15,350 postcalving samples. A total of 9,426 pairs of samples (1 taken from a quarter between 4 and 2 wk before dry-off and 1 taken from the same quarter between 2 wk and dry-off) from predry-period cows were included in the analysis. Of these, $1,845(20 \%)$ were positive for CNS in the first sample of the pair, 407 (4.3\%) were positive for Corynebacterium spp. in the first sample, and $159(1.7 \%)$ were positive for both minor pathogens in the first sample. Postcalving cow sample pairs (pairings of 1 sample taken within $24 \mathrm{~h}$ of calving and 1 sample taken 1 to 2 wk after calving) numbered 7,053 and had 1,249 (18\%) positive for CNS and 167 (2.4\%) positive for Corynebacterium spp. in the first sample of the pair; $85(1.2 \%)$ were positive for both minor pathogens. For midlactation samples, a total of 80,397 quarter milk samples were available, and only subsequent pairings of samples were considered (samples taken in wk 1 were paired only with those taken in wk 2, whereas samples taken in wk 2 were paired both with those taken in wk 1 and those taken in wk 3 , and so on). Of these 58,841 pairs, 9,709 (17\%) were positive for CNS in the first sample and 2,262 $(3.8 \%)$ were positive for Corynebacterium spp. A total of $629(1.1 \%)$ of these were infected with both CNS and Corynebacterium spp.

Results of the risk ratio ( $R \mathbf{R}$ ) analyses are given in Table 1. Considering all sample types together (predry-off, postcalving, and midlactation), the analyses indicated that the presence of a CNS IMI in a mammary quarter was a significant risk factor for development of a new infection only with Staph. aureus $(\mathrm{RR}=1.4 ; 95 \%$ $\mathrm{CI}=1.1-1.6)$.

When samples were stratified by sample type, the presence of a CNS IMI was a significant risk factor for Staph. aureus in pre-dry-off samples $(\mathrm{RR}=1.57$; $95 \% \mathrm{CI}=1.03-2.41)$ and midlactation samples $(\mathrm{RR}=$ $1.29 ; 95 \%$ CI $=1.02-1.64)$. Similarly, when $E$. coli was analyzed separately, CNS IMI was a risk factor for $E$. coli in postcalving cow samples $(\mathrm{RR}=2.9 ; 95 \% \mathrm{CI}=$ 1.0-8.0; data not shown). 


\section{Total samples}

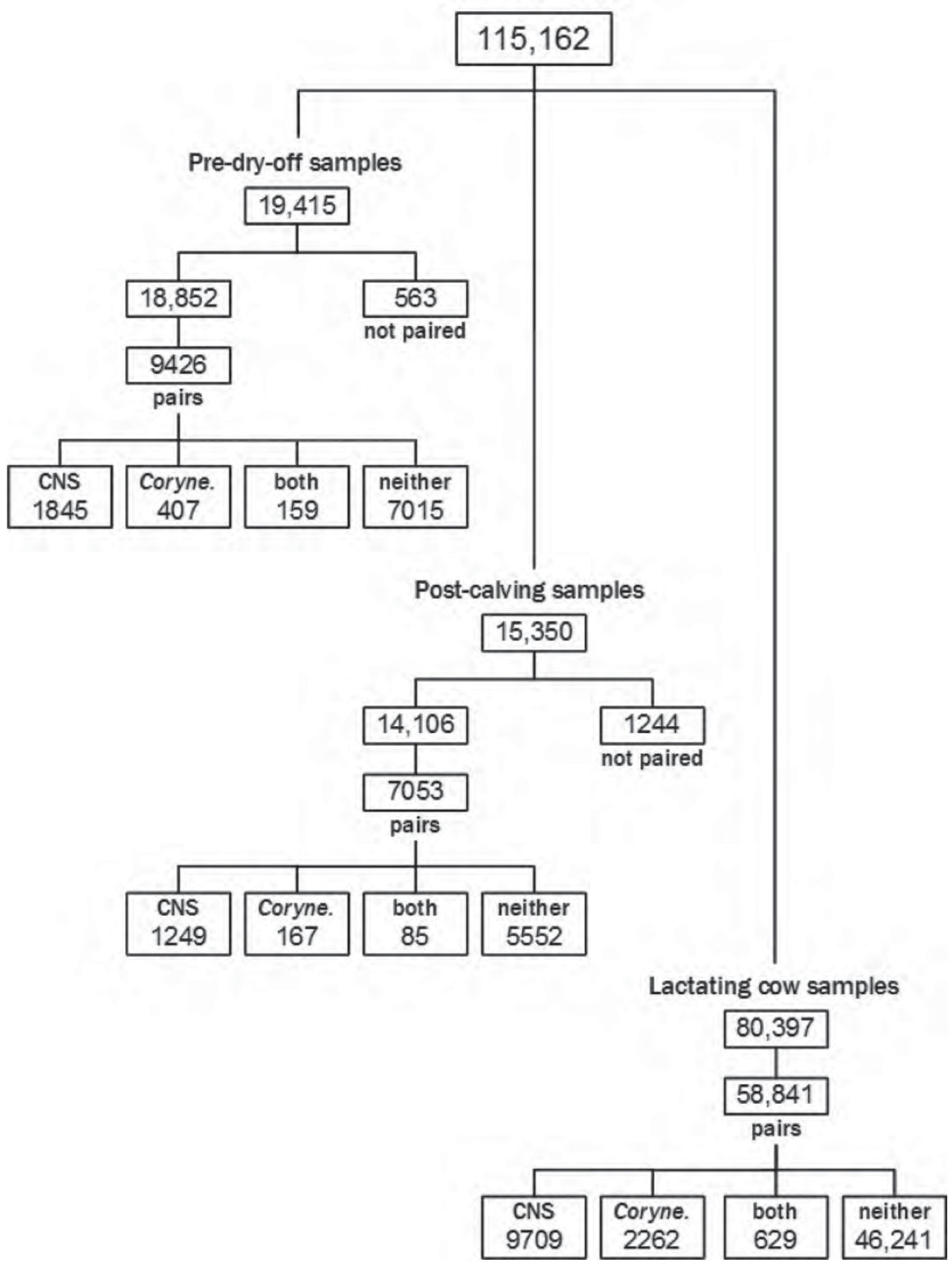

Figure 1. Data flowchart illustrating the data used in the risk ratio analyses. Coryne. = Corynebacterium spp.

\section{Multilevel Logistic Regression}

Only midlactation samples were included in these analyses, as it was determined that estimation of the susceptibility parameters for pre-dry-off and postcalv- ing samplings would have been very imprecise, being based on only 1 measurement. An example of the data used for the multilevel logistic model analyses is detailed in Figure 2. These analyses used a random selection of 20,112 samples out of these 80,397 quarter milk sam- 
Table 1. Results of risk ratio analyses for the major pathogens (including 95\% CI in parentheses)

\begin{tabular}{lcc}
\hline Pathogen & $\mathrm{CNS}$ & $\begin{array}{c}\text { Corynebacterium } \\
\text { species }\end{array}$ \\
\hline All samples & & \\
$\quad$ Staphylococcus aureus & $1.4(1.1-1.6)^{*}$ & $0.9(0.6-1.4)$ \\
$\quad$ Streptococcus uberis & $1.1(0.6-1.7)$ & $1.0(0.4-2.3)$ \\
Streptococcus dysgalactiae & $0.8(0.4-1.3)$ & $0.6(0.2-1.9)$ \\
Coliforms & $1.0(0.7-1.5)$ & $1.0(0.5-2.0)$ \\
Pre-dry-off samples only & & \\
Staph. aureus & $1.6(1.0-2.4)^{*}$ & $1.5(0.8-3.0)$ \\
Strep. uberis & $\mathrm{N} / \mathrm{A}^{1}$ & $1.6(0.2-12.2)$ \\
Strep. dysgalactiae & $0.4(0.1-1.9)$ & $0.9(0.1-6.5)$ \\
Coliforms & $0.5(0.1-3.7)$ & $\mathrm{N} / \mathrm{A}$ \\
Postcalving samples only & & \\
Staph. aureus & $1.1(0.6-2.1)$ & $1.4(0.4-4.3)$ \\
Strep. uberis & $0.8(0.2-3.5)$ & $\mathrm{N} / \mathrm{A}$ \\
Strep. dysgalactiae & $0.5(0.1-4.3)$ & $\mathrm{N} / \mathrm{A}$ \\
Coliforms & $2.1(0.8-5.7)$ & $\mathrm{N} / \mathrm{A}$ \\
Lactation samples only & & \\
Staph. aureus & $1.3(1.0-1.6)^{*}$ & $0.7(0.4-1.2)$ \\
Strep. uberis & $1.3(0.8-2.2)$ & $1.0(0.4-2.7)$ \\
Strep. dysgalactiae & $0.9(0.5-1.7)$ & $0.6(0.1-2.3)$ \\
Coliforms & $1.0(0.6-1.5)$ & $1.2(0.6-2.5)$ \\
\hline
\end{tabular}

${ }^{1} \mathrm{~N} / \mathrm{A}$ indicates results where there were no new IMI in that sample type.

$* P \leq 0.05$.

ples. One record (the sampling before a NIMI occurring for quarters where a NIMI was present and a randomly chosen sampling for quarters where no NIMI occurred) from each of 20,112 quarters was used. Of these, 5,465 were from the spring 2007 sampling period, 5,385 were from the summer 2007 sampling period, 4,656 were from the winter 2008 sampling period, and 4,606 were from the summer 2008 sampling period. Two hundred and fifty-eight Staph. aureus NIMI, 56 Strep. uberis NIMI, 49 Strep. dysgalactiae NIMI, and 122 coliform NIMI were included in these data. The mean of the proportion of quarters positive for any organism (an estimate of quarter-level susceptibility) was 0.25 (SD $=0.29$ ) and the distribution was right skewed (Figure 3). This indicates that, on average, quarters were positive for a mastitis pathogen in $25 \%$ of samplings within a sampling period. As can be seen from Figure 3 , many were never positive for a mastitis pathogen (and thereby not considered very susceptible), although some were positive $100 \%$ of the time (considered very susceptible). Similar results were found when the proportion of samples positive were aggregated at the cow level (mean $=0.25, \mathrm{SD}=0.18$; Figure 4 ) and herd level $($ mean $=0.25, \mathrm{SD}=0.08$; Figure 5$)$ as estimates of cow- and herd-level susceptibility. The mean of $\operatorname{lnSCC}$ was $3.3(\mathrm{SD}=1.5)$ which back-transforms to a geometric mean SCC of 27,000 cells $/ \mathrm{mL}(\mathrm{SD}=4,500$ cells/ $\mathrm{mL}$ ), and the distribution was right skewed (Figure 6).

Continuous predictors were evaluated for linearity in relation to the outcome. Lactation number was dichotomized into first lactation and second-or-greater lactation. Days in milk at the time of sampling was

58,841

matched sets of quarter milk samples
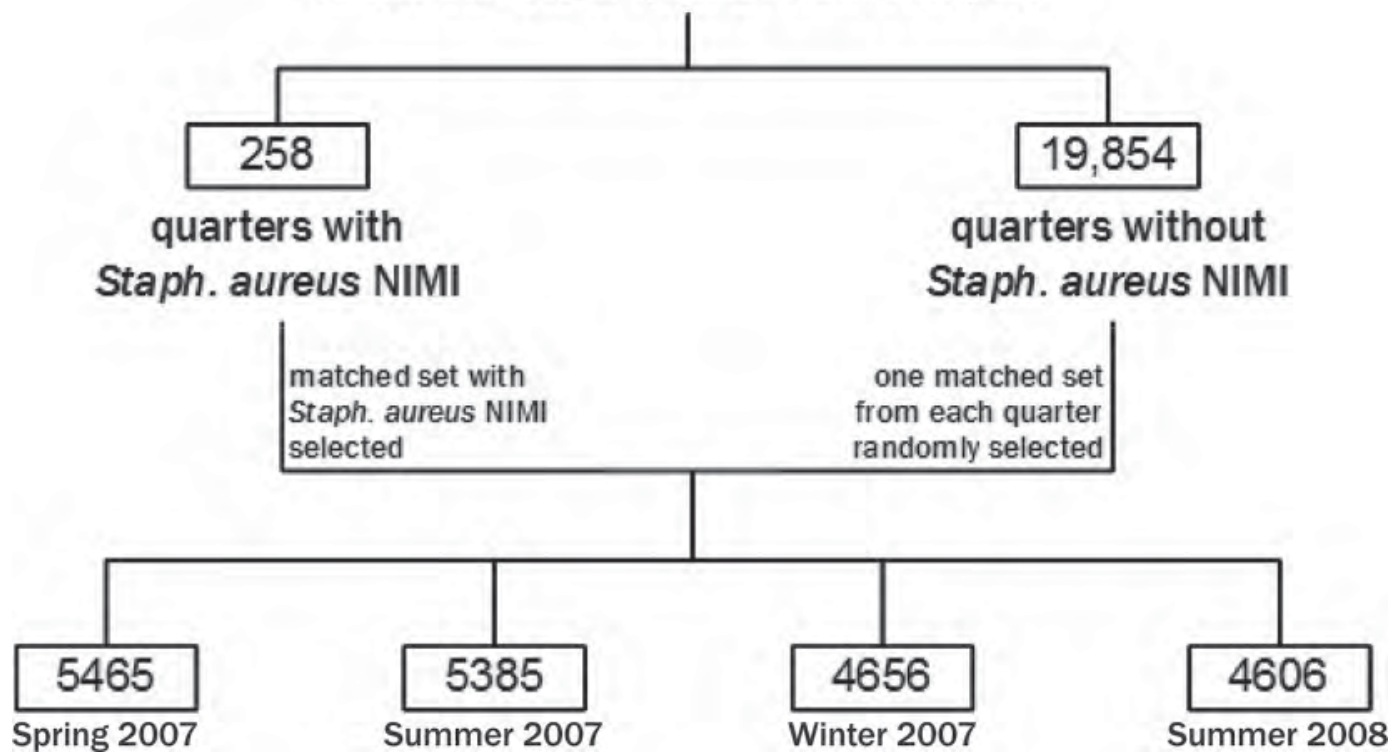

Figure 2. Data flowchart illustrating the data used in the multilevel logistic regression model analyses. Staph. = Staphylococcus; NIMI $=$ new IMI. 


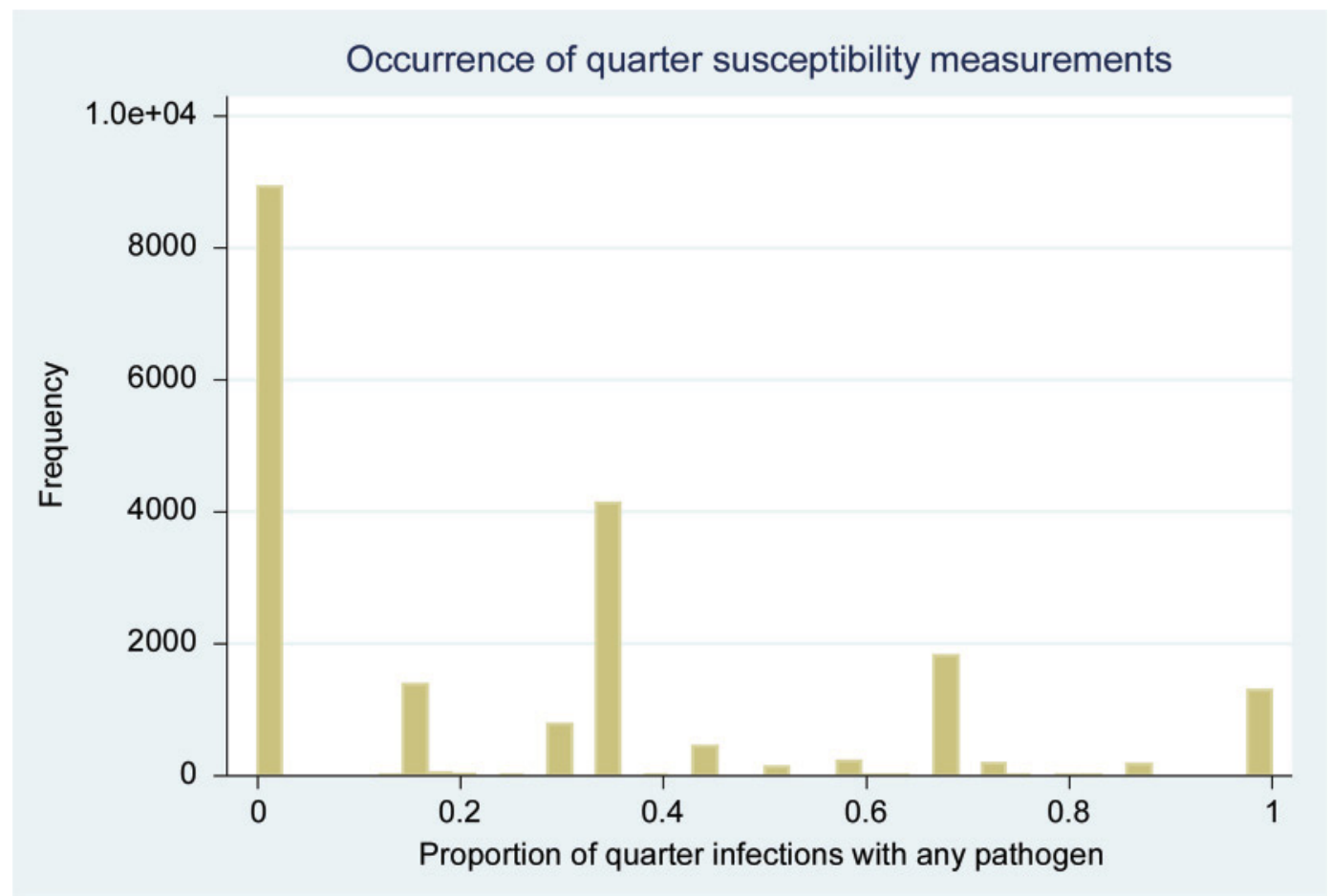

Figure 3. Distribution of the proportion of samplings in any one quarter that was positive for any organism of interest (an estimate of quarter-level susceptibility). Color version available in the online PDF.

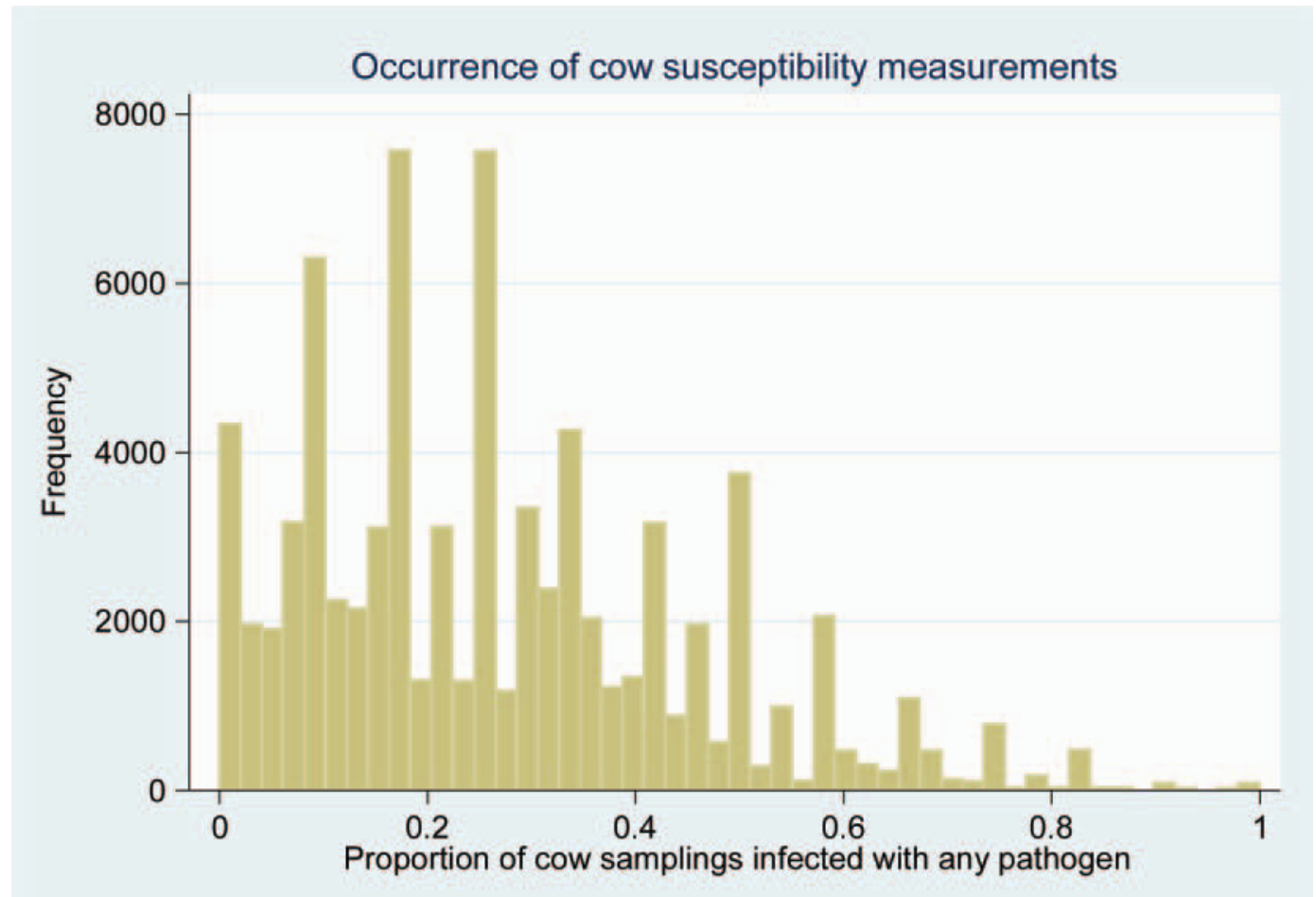

Figure 4. Distribution of the proportion of samplings in a cow that was positive for any organism of interest (an estimate of cow-level susceptibility). Color version available in the online PDF. 


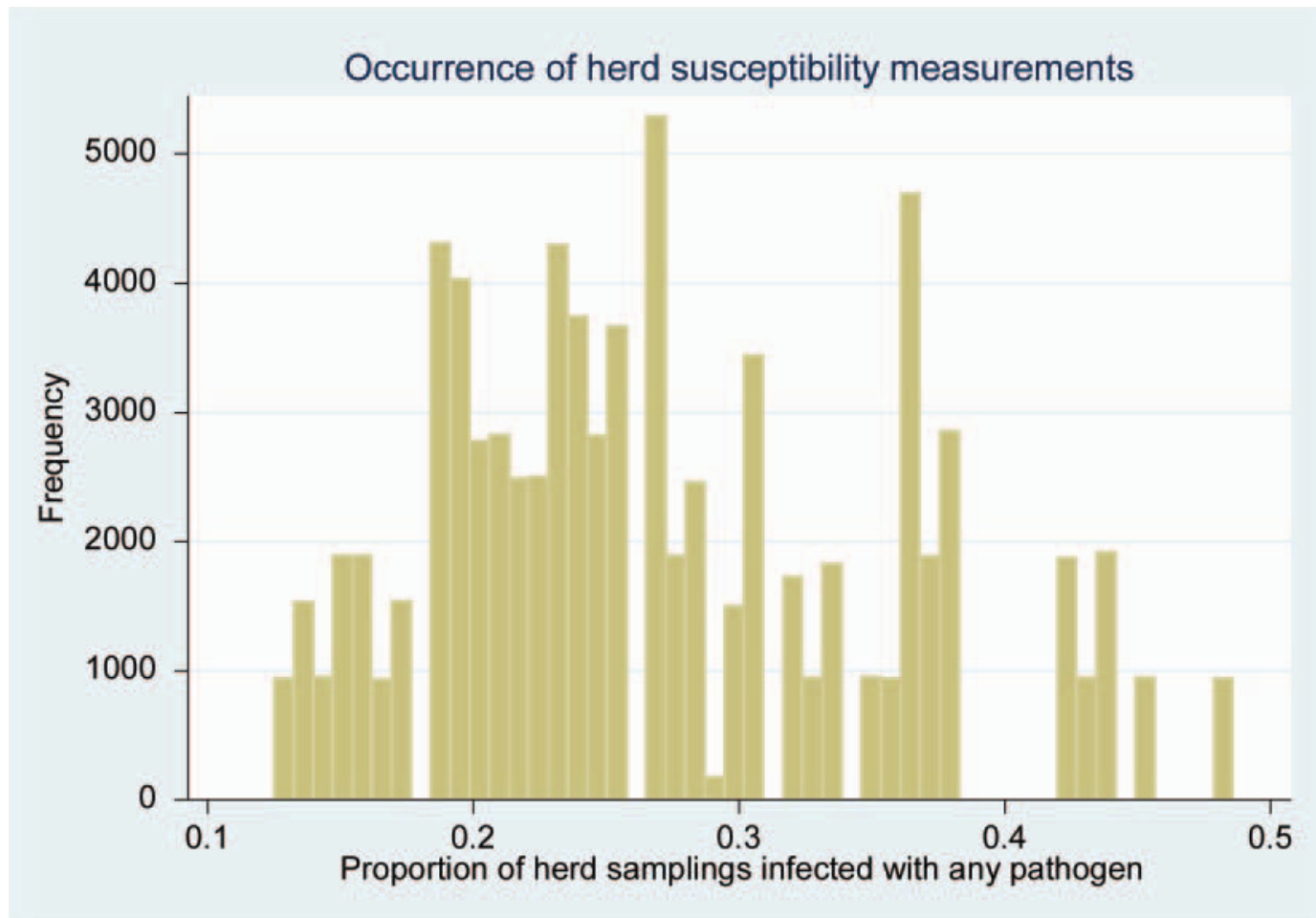

Figure 5. Distribution of the proportion of samplings within a herd that was positive for any organism of interest (an estimate of herd-level susceptibility). Color version available in the online PDF.

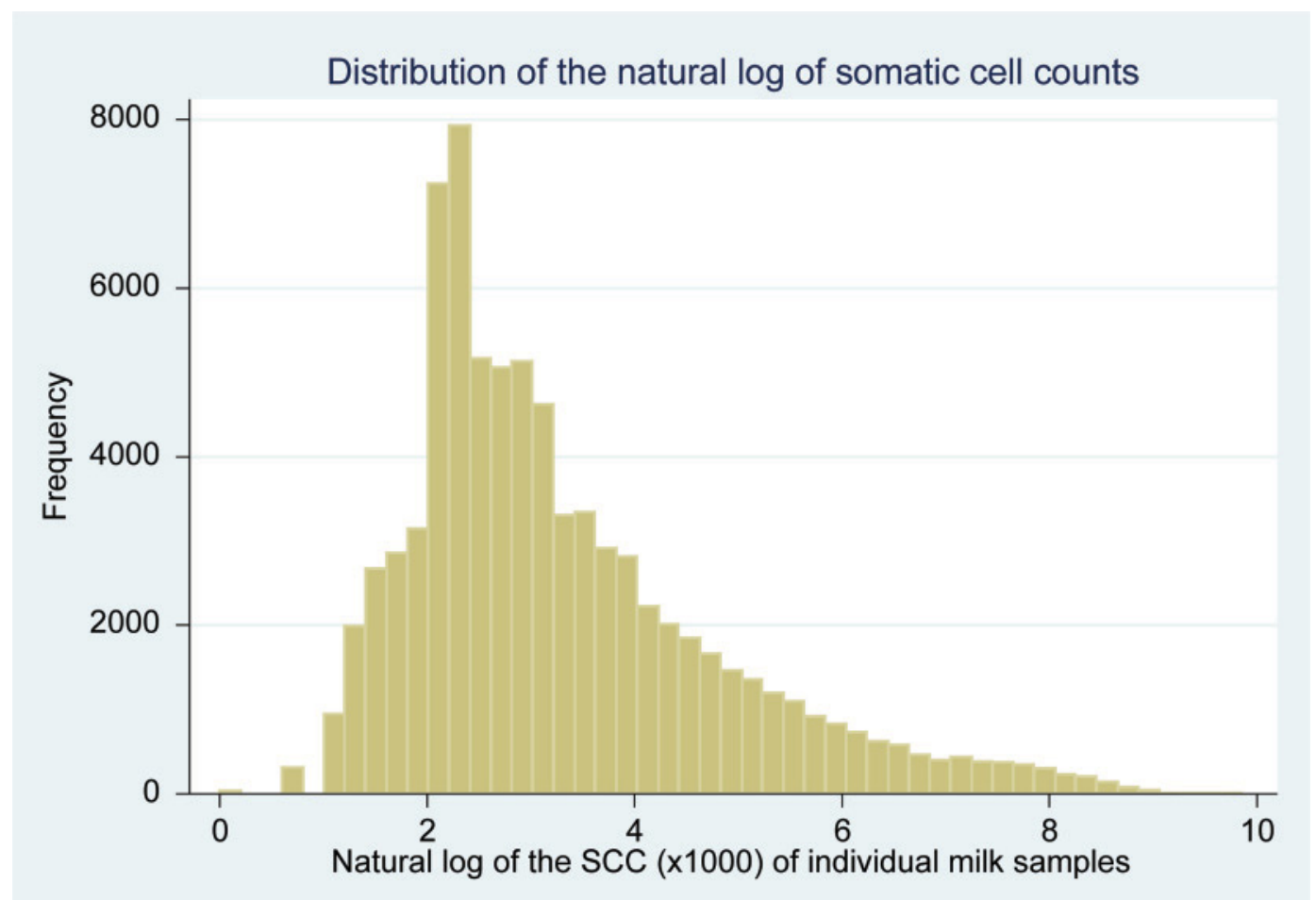

Figure 6. Distribution of the natural logarithm transformation of SCC for each of the individual milk samples. Color version available in the online PDF. 
found to have a linear relationship with respect to the outcome. Similarly, $\operatorname{lnSCC}$ was also linear with respect to the outcome. The interaction (cross-product) between CNS and Corynebacterium spp. was initially evaluated; however, it was not found to be statistically significant in any of the models, and was, therefore, excluded. Susceptibility parameters - the proportion of samples in a series that were positive for any of the previously mentioned organisms (except the organism of interest) - were computed and included. Unconditional associations revealed that many of these proportions had a quadratic relationship with the outcome, so these were centered and squared for inclusion as such in the models. If the quadratic terms were not significant in the final models, they were not included. Proportions were also calculated using any organism cultured by CBMRN laboratories (including those normally associated with environmental contamination), but inclusion of these made very little difference in the estimates in the final models, so proportions calculated using the previously mentioned organisms only were used.

Odds ratios (OR) and their confidence intervals for the predictors in each of the models are given in Table 2. Odds ratios greater than 1.0 indicate an association with increased risk of major pathogen NIMI, whereas OR less than 1.0 indicate association with protection against a NIMI. In general, the only significant predictors $(P \leq 0.05)$ were the $\operatorname{lnSCC}$ in the sample before occurrence of the NIMI and the quarter-level susceptibility parameters. The odds of a quarter developing a NIMI as a cow progressed through lactation did not seem to alter definitively, even with a 100-d change, and was usually not very different from the no-effect value of 1.0. Overall, no distinct trend was seen between samples taken weekly (summer 2007, the baseline of the models) and samples taken every $3 \mathrm{wk}$, although for coliforms, a significant difference between weekly and tri-weekly sampling was observed: tri-weekly sampling had a lower OR of a quarter acquiring a NIMI. As the lnSCC in the previous milk sample increased by 1 unit, the OR of a quarter developing a NIMI with a major pathogen was between 1.6 and 2.0 (Table 2). This was a significant result for all of the major pathogens. No significant difference was seen for a change in the lnSCC in samples taken 2 samplings before the occurrence of a NIMI. The presence of CNS in the sample 2 samplings before the occurrence of a NIMI increased the odds of experiencing a Staph. aureus NIMI 2.0 times $(P=$ 0.009), making presence of CNS a risk factor for acquiring a Staph. aureus NIMI. No significance of the presence of Corynebacterium spp. was found on the odds of developing an infection with any major pathogen, and most values were very close to the value for no effect.

Being from a herd with increased susceptibility for infection (i.e., those herds where many quarters cultured mastitis pathogens often) was not significantly associated with the odds of acquiring a major pathogen NIMI. As the susceptibility of a cow increased (for instance, in a comparison between a cow that rarely cultured positive for mastitis pathogens and a cow that

Table 2. Odd ratios of acquiring a new IMI (NIMI) with a major pathogen from multilevel logistic models (including 95\% CI in parentheses)

\begin{tabular}{|c|c|c|c|c|}
\hline Item & $\begin{array}{c}\text { Staphylococcus } \\
\text { aureus }\end{array}$ & $\begin{array}{c}\text { Streptococcus } \\
\text { uberis }\end{array}$ & $\begin{array}{c}\text { Streptococcus } \\
\text { dysgalactiae }\end{array}$ & Coliforms \\
\hline \multicolumn{5}{|l|}{ Potential confounder } \\
\hline Lactation $>1$ & $1.0(0.6-1.6)$ & $0.9(0.3-2.3)$ & $1.1(0.3-4.4)$ & $1.6(0.8-4.4)$ \\
\hline DIM, 100-d change & $0.8(0.7-1.0) \dagger$ & $0.9(0.6-1.3)$ & $0.6(0.3-1.1)$ & $0.9(0.7-1.2)$ \\
\hline Winter 2007 sampling & $1.2(0.7-2.0)$ & $0.3(0.1-1.3)$ & $0.0(0.0-100+)$ & $0.1(0.0-0.3)^{*}$ \\
\hline Winter 2008 sampling & $0.9(0.5-1.6)$ & $0.3(0.1-1.4)$ & $1.2(0.3-4.5)$ & $0.1(0.0-0.4)^{*}$ \\
\hline Summer 2008 sampling & $0.5(0.3-1.0) \dagger$ & $0.6(0.2-1.9)$ & $0.6(0.1-3.0)$ & $0.6(0.3-1.4)$ \\
\hline \multicolumn{5}{|l|}{ Susceptibility parameter } \\
\hline Herd susceptibility & $2.5(0.1-100+)$ & $0.1(0.0-19.9)$ & $0.2(0.0-100+)$ & $0.0(0.0-7.4)$ \\
\hline Cow susceptibility & $0.9(0.2-4.5)$ & $9.4(0.5-100+)$ & $0.6(0.0-33.6)$ & $6.0(0.7-50.0) \dagger$ \\
\hline Quarter susceptibility & Figure $7^{*}$ & Figure $8^{*}$ & Figure $9^{*}$ & $0.2(0.1-1.0)^{*}$ \\
\hline \multicolumn{5}{|l|}{ SCC } \\
\hline $\operatorname{lnSCC} 2$ samples prior $^{1}$ & $1.1(0.9-1.3)$ & $1.1(0.8-2.7)$ & $1.3(0.9-1.9)$ & $0.9(0.7-1.2)$ \\
\hline lnSCC in prior sample & $1.7(1.4-2.0)^{*}$ & $2.0(1.5-2.7)^{*}$ & $1.8(1.2-2.7)^{*}$ & $1.6(1.3-2.0)^{*}$ \\
\hline \multicolumn{5}{|l|}{ Minor pathogen IMI } \\
\hline CNS 2 samples prior & $2.0(1.2-3.4)^{*}$ & $2.1(0.8-5.8)$ & $0.2(0.0-1.5)$ & $0.9(0.4-2.2)$ \\
\hline CNS in prior sample & $1.1(0.6-1.9)$ & $1.1(0.4-3.4)$ & $0.7(0.2-3.1)$ & $1.5(0.7-3.3)$ \\
\hline Corynebacterium spp. 2 samples prior & $0.9(0.3-2.2)$ & $0.8(0.2-4.6)$ & $1.1(0.1-13.1)$ & $2.1(0.6-6.6)$ \\
\hline Corynebacterium spp. in prior sample & $1.1(0.5-2.5)$ & $2.9(0.6-12.8)$ & $0.4(0.0-6.1)$ & $0.2(0.0-1.1) \dagger$ \\
\hline \multicolumn{5}{|l|}{ Variance estimate } \\
\hline Herd-level variance & $0.9(0.6-1.3)$ & $0.4(0.0-43.2)$ & $1.2(0.5-2.8)$ & $1.3(0.9-1.9)$ \\
\hline Cow-level variance & $1.5(1.0-2.1)$ & $1.9(1.0-3.6)$ & $2.2(1.0-5.1)$ & $2.2(1.6-3.1)$ \\
\hline
\end{tabular}

${ }^{1}$ Prior indicates prior to the occurrence of a NIMI.

${ }^{*} P \leq 0.05 ; \dagger P \leq 0.10$. 
often cultured positive for mastitis pathogens), a trend for increased risk of acquiring a NIMI occurred with Strep. uberis or coliforms; no significance was achieved for the other major pathogens. Quarter susceptibility seemed to have a quadratic relationship with the outcome for all major pathogens except the coliforms, and increased quarter susceptibility was associated with increased risk of major pathogen NIMI with Staph. aureus, Strep. uberis, and Strep. dysgalactiae (i.e., quarters that more often cultured positive for mastitis pathogens were more likely to acquire NIMI with Staph. aureus, Strep. uberis, and Strep. dysgalactiae). It is important to note that in the following figures, the amount of data used for prediction became scarce when the proportion of samples positive for any organism was greater than approximately 0.5 (Figure 3); in fact, less than $20 \%$ of quarter susceptibility measurements were above 0.5 . This is also illustrated by the wide confidence intervals on the quarter-susceptibility graphs (Figures 7-9). As the proportion of samples from a quarter that was infected with any organism rose from 0 to approximately 0.3 , the OR of that quarter acquiring a Staph. aureus NIMI rose slightly (to $\mathrm{OR}=1.3$ ). For susceptibility measurements of 0.3 to 0.5 , the OR of NIMI did not increase further, but more susceptible quarters were still associated with increased risk of acquiring a Staph. aureus NIMI (OR $>1$; Figure 7). Similarly, as the proportion of samples from a quarter that were infected with any organism rose from 0 to 0.25 , the OR of that quarter acquiring a NIMI with Strep. uberis also rose from 1.0 to 1.3 (Figure 8). As susceptibility continued to increase to 0.5 , the OR again did not continue to increase, but was always greater than 1.0, indicating increased risk of acquiring a Strep. uberis NIMI. For Strep. dysgalactiae, the OR of a quarter acquiring a NIMI increased continuously over the susceptibility range 0 to 0.5 , with $\mathrm{OR}$ climbing from 1 to approximately 3 , although the confidence intervals were also very wide (Figure 9). These graphs indicate that having a quarter that is generally more susceptible to infection represents a risk for acquiring a NIMI with all of the major pathogens except coliforms. Quarters were about one-fifth as likely to acquire a coliform NIMI as the proportion of quarters infected with any pathogen changed from 0 to $1(\mathrm{OR}=0.2, P=0.05)$.

The random effects models for each of the pathogens accounted for the clustering of observations within cows and herds. The variance at the cow level averaged 2.0 , with a range of 1.5 to 2.2 , indicating that significant clustering occurred at the cow level. The average cow-level ICC was 0.46 (range $0.41-0.52$ ); most of the unexplained variation in the acquisition of new NIMI, therefore, is within individual cows. The variance at the herd level averaged 1.0, with a range of 0.4 to 1.3 ,

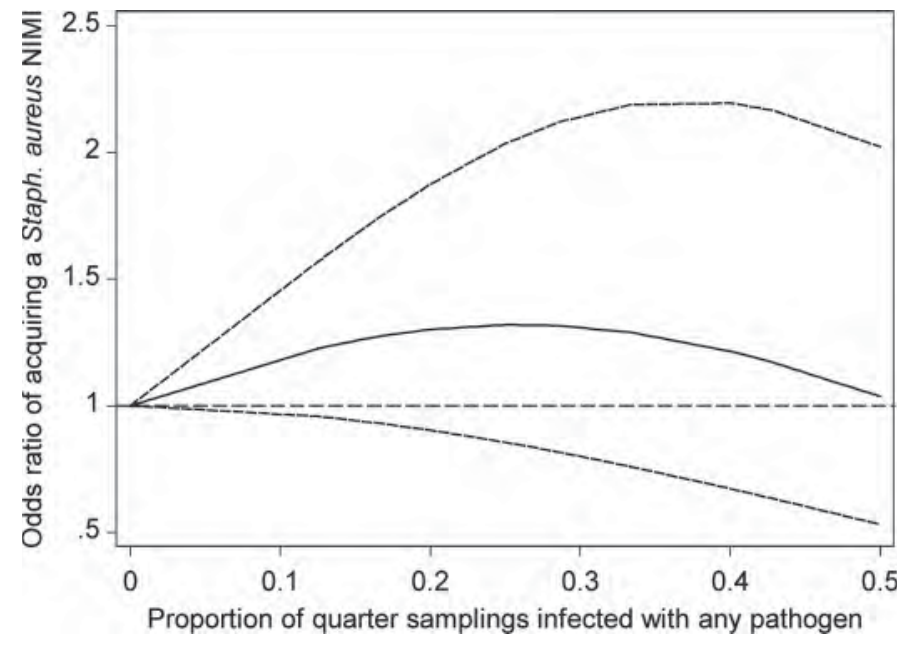

Figure 7. Quadratic relationship between the odds of acquiring a new IMI (NIMI) with Staphylococcus aureus (relative to the odds with no quarter samplings infected) and quarter susceptibility measurements (95\% CI are included as dashed lines).

indicating less clustering at the herd level, although herd-level clustering was significant in all models but the Strep. uberis model. The average herd-level ICC was 0.15 (range 0.07-0.19), so less unexplained variation exists between cows or within individual herds.

A separate set of models were run to include the number of CNS cultured $(\mathrm{cfu} / \mathrm{mL})$ to determine if an infection dose effect was present. The number of CNS were categorized into 4 categories: no CNS present, $100 \mathrm{cfu} / \mathrm{mL}$ cultured, 200 to $900 \mathrm{cfu} / \mathrm{mL}$ cultured, and 1,000 or greater $\mathrm{cfu} / \mathrm{mL}$ cultured, to obtain approximately equal group sizes. No consistent effects either

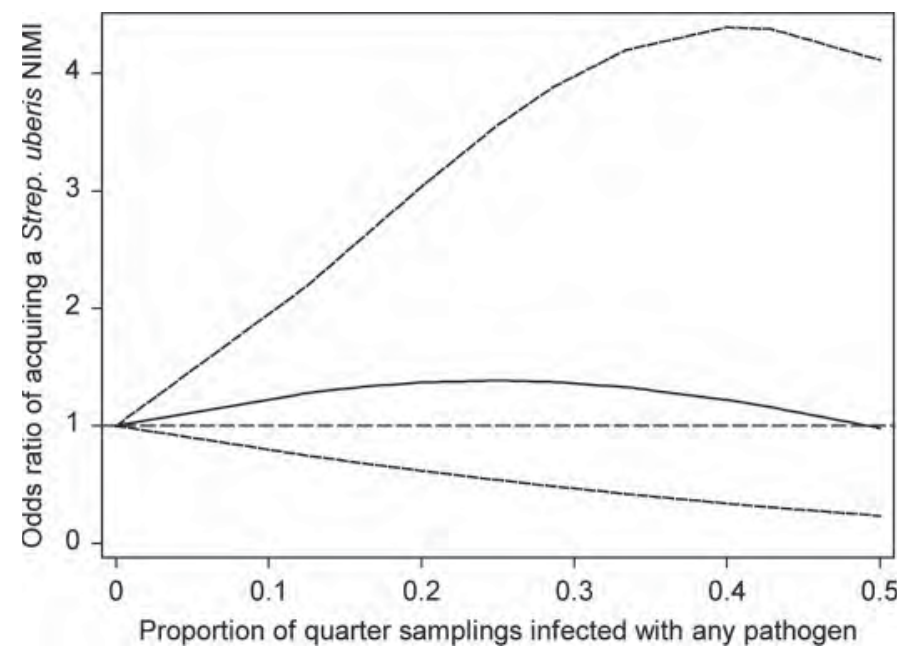

Figure 8. Quadratic relationship between the odds of acquiring a new IMI (NIMI) with Streptococcus uberis (relative to the odds with no quarter samplings infected) and quarter susceptibility measurements (95\% CI are included as dashed lines). 


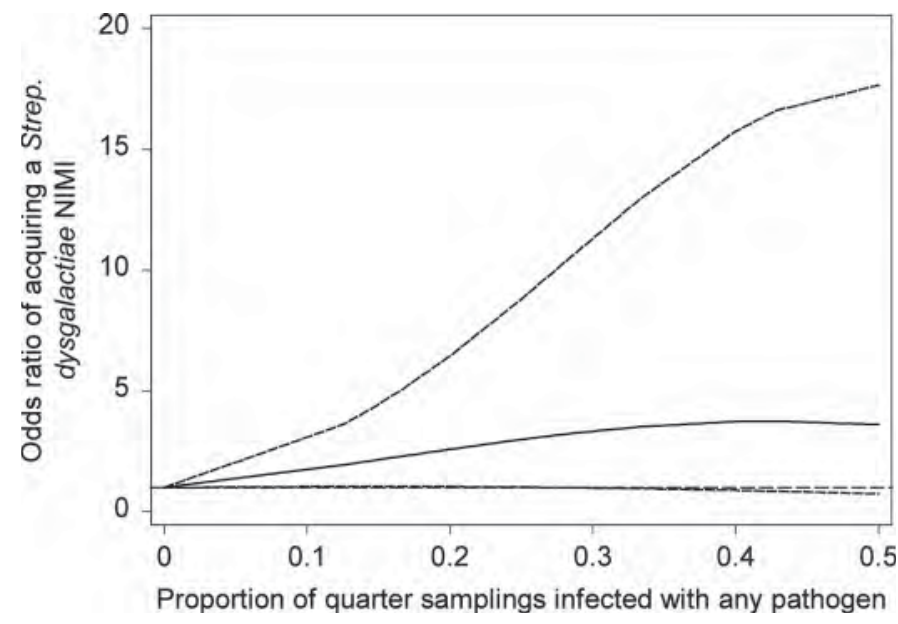

Figure 9. Quadratic relationship between the odds of acquiring a new IMI (NIMI) with Streptococcus dysgalactiae (relative to the odds with no quarter samplings infected) and quarter susceptibility measurements (95\% CI are included as dashed lines).

within the pathogens or across major pathogens were seen as the infection dose of CNS cultured increased (data not presented).

\section{DISCUSSION}

These analyses sought to shed light on the effect of naturally occurring minor pathogen IMI on acquisition of NIMI with major pathogens. Although experimental evidence reveals much about the specific interactions between particular strains of pathogens, observational studies offer information about what may be occurring in field situations. Longitudinal data can assist in revealing causal relationships as time series is clearly defined and a clearer picture of the progression of disease can be seen as a particular quarter or cow is followed over time. The interactions between quarter, cow, and herd can be accounted for, and provide information about, the amount of variation at specific levels. Data such as those presented here can offer much in the way of information regarding major and minor pathogen interactions.

\section{Definitions and Misclassification Bias}

The definition of IMI used here $(>100 \mathrm{cfu} / \mathrm{mL}$ in a single sample for major pathogens and Corynebacterium spp. and $>200 \mathrm{cfu} / \mathrm{mL}$ in a single sample for CNS) differs from that of previous authors, but is believed it to provide a good balance between Se and Sp (Dohoo et al., 2011b). Maximizing Se for major pathogen infections, as this definition does, served to identify as many NIMI as possible while still achieving a high Sp. False positives were less of a concern, as this definition has Sp greater than $99 \%$ for the major pathogens considered (Dohoo et al., 2011b). Coagulase-negative staphylococci IMI were defined more strictly to prevent false-positive results (increasing Sp from $87 \%$ to $95 \%$ ), as these organisms occur on teat skin and, although found in milk samples, may not always be the cause of IMI. This did decrease the Se of isolating CNS from 81 to $56 \%$, so potentially several CNS infections were not identified. If a less strict definition was applied (e.g., $100 \mathrm{cfu} / \mathrm{mL}$ ), the presence of these organisms might have contributed more to the susceptibility parameters and increased the collinearity between the susceptibility parameters and the presence of CNS in the 2 prior samples. This would have served to decrease the estimates for the associations of CNS or Corynebacterium spp. toward the null, so the possibility exists that the OR presented here may be overestimated. This stricter definition of CNS that was used might have decreased the chance of observing CNS in either of the prior samples, which would serve to underestimate the association between CNS and a major pathogen NIMI. Either type of bias may exist, therefore, but it was believed that the introduction of these potential misclassification biases was preferable to finding an effect based on a falsely positive diagnosis with CNS. Additionally, analyses were completed to assess an infection dose effect of CNS and included $100 \mathrm{cfu} / \mathrm{mL}$ or more colonies of CNS, but no more significance was identified above what was seen than was seen in the models with $200 \mathrm{cfu} / \mathrm{mL}$ of $\mathrm{CNS}$ included.

\section{Risk Ratios}

Some of the shortcomings of the previous literature were avoided by utilizing a definition of IMI with known Se and Sp, by adjusting for clustering within cows and within herds, and by being able to model herd-, cow-, and quarter-level susceptibility. To establish unconditional associations and to use all of the data (pre-dry-off and postcalving samples), risk ratios were calculated. These risk ratio estimates do not take into account the clustered nature of the data and, therefore, may reveal more significance than is actually present in the data, but they provide some insight into the associations that exist between minor pathogen IMI and major pathogen NIMI. The only association with statistical significance $(P \leq 0.05)$ was the association with increased risk conferred by CNS IMI for NIMI with Staph. aureus. This association was also found to have significance in the multilevel logistic models, albeit at 2 samplings before. Additionally, this effect was particularly significant in pre-dry-off and midlactation samples, indicating that CNS infection at times of mid- or late lactation might 
put the quarter at higher risk for obtaining a Staph. aureus infection.

\section{SCC}

Parameters representing the natural $\log$ of SCC 1 and 2 samplings before a NIMI with a major pathogen were included in these models to investigate the previously reported protective effect of SCC on the acquisition of a major pathogen NIMI. The results were interesting, as the $\operatorname{lnSCC}$ in the sample before diagnosis of a NIMI was always significantly associated with increased risk of acquiring a NIMI with all of the major pathogens $(P \leq 0.004)$. It is believed that this result is, in large part, due to the major pathogen NIMI being diagnosed 1 sampling too late by bacteriological examination. A significant increase in SCC usually accompanies an IMI with a major pathogen (Djabri et al., 2002) and the strongly significant association of $\operatorname{lnSCC}$ with the risk of acquiring a major pathogen NIMI likely reflects the fact that inflammation accompanying infection existed, although bacteriological evidence of the NIMI was not yet identified. This association does not exist between the outcome and the $\operatorname{lnSCC}$ in the sample taken 2 samplings before the NIMI was diagnosed, indicating that an increase in SCC preceded the diagnosis of NIMI by just 1 sampling. To investigate possible collinearity effects of including both lnSCC parameters, models were fit with only 1 of the SCC parameters, but no substantial differences were identified. Deluyker et al. (1993) have previously shown that SCC is significantly increased up to $10 \mathrm{~d}$ before diagnosis with clinical mastitis, and the data presented here represents samples taken weekly or tri-weekly. Dohoo et al. (2011b) have also shown the sensitivity of bacteriological examination for these major pathogens to range from 29.1 to $90.4 \%$, so it is probable that several NIMI with these pathogens were identified 1 sampling late. For a pathogen with an Se of $80 \%$, for instance, it would be expected that only 80 of 100 NIMI would be identified in the first sample and 16 of the remaining 20 NIMI in the second sample. With a low Se for bacteriology in diagnosing major pathogen NIMI, therefore, it is not surprising that several NIMI were missed by bacteriology in an earlier sampling, as revealed by SCC. It also does not seem that a higher $\operatorname{lnSCC}$ in samples 2 samples before diagnosis of a NIMI has any relationship with the risk of a NIMI with a major pathogen being diagnosed.

Several papers have suggested that the increased SCC caused by IMI (with minor or major pathogens) may offer protection against the acquisition of NIMI (Forbes, 1970; Postle et al., 1978; Rainard and Poutrel, 1988; Schukken et al., 1999). Schukken et al. (1999) described a protective effect for increased $\operatorname{lnSCC}$ as measured in samples taken immediately before Staph. aureus challenge that were negative for major pathogens. This effect was separate from a protective effect that was also shown for Corynebacterium bovis prechallenge, suggesting that both increased SCC and $C$. bovis may have protective effects against major pathogen NIMI. Care must be taken in interpreting the results of experimental studies such as these, however, as the first line of defense (the teat end) is often bypassed by infusion of challenge organisms, making it difficult to compare them to the observational literature. Other studies have shown increased risk of clinical mastitis as SCC rises (Dohoo et al., 1984; Beaudeau et al., 1998; Rupp et al., 2000; Rupp and Boichard, 2000; Whist and Østerås, 2007). As bacteriological culturing was not done on these quarters and clinical mastitis was used as the outcome, these papers are presumably documenting the increased probability that cows with subclinical IMI are more likely to develop clinical mastitis. In a paper similar to the work presented here, where IMI was used as the outcome (instead of clinical mastitis), Zadoks et al. (2001) showed higher levels of SCC (>500,000 cells/ $\mathrm{mL}$ ) in samples taken $3 \mathrm{wk}$ before diagnosis of new IMI with Staph. aureus to be associated with increased risk of new quarter-level IMI with that pathogen (rate ratio $=2.9-3.1$ in 3 models, all $P \leq 0.01$ ). These analyses, similar to those in the present study, were presumably identifying cows with underlying infections that were bacteriologically latent, as new IMI were diagnosed over a period of time after suggested recovery from previous IMI with Staph. aureus (Zadoks et al., 2001).

\section{Minor Pathogens}

It is interesting that the presence of a CNS IMI in the sample taken 2 samplings prior was significantly associated with an increase in risk for a NIMI with Staph. aureus $(\mathrm{OR}=2.0 ; P=0.009)$. Previous models including data from only 1 sampling before a NIMI had shown the presence of a CNS IMI in the prior sample to be significantly associated with the risk of acquiring a Staph. aureus NIMI, and, though not significant, this relationship also exists for Strep. uberis. Although several studies have found protection provided by CNS against Staph. aureus, others have found its association with increased risk of NIMI. First, the results of experimental models that found protective effects of CNS against Staph. aureus are difficult to compare with the results of observational studies that seek to understand the natural experience. Among observational studies, then, Matthews et al. (1991), Rainard and Poutrel (1988), and Schukken et al. (1989) all identified a protective effect of CNS on Staph. aureus NIMI, although these studies performed straightforward analyses with- 
out accounting for clustering within the data or for any susceptibility within quarters, cows, or herds. Piepers et al. (2011) found a protective effect for CNS colonizing the teat apex; this result is different from an actual IMI caused by CNS, although these researchers did account for cow- and herd-level clustering. Lam et al. (1997) found evidence of higher rates of infection with Staph. aureus in CNS-positive quarters in their descriptive data, and attributed this to cow-level confounding. They went on to account for cow-level confounders by using a matched case-control study; however, a significant effect using just coagulase-negative Micrococcaceae was not found ( $\mathrm{OR}=0.86 ; 95 \% \mathrm{CI}=0.4-1.85)$. Two studies do report an association of CNS IMI with risk of Staph. aureus NIMI. Parker et al. (2007) found that heifers with precalving CNS IMI had an increased risk of postcalving IMI with Staph. aureus $(\mathrm{RR}=6.56 ; 95 \%$ $\mathrm{CI}=1.4-31.7)$. Berry and Hillerton (2002) observed an increased risk for Staph. aureus after calving of 2 times for quarters infected with CNS at drying off, although this was not significant. These results, however, were unconditional risk ratios, and none of these analyses modeled the susceptibility at the quarter, cow, or herd level as has been done in the models presented here.

No significant associations were found between the presence of CNS and NIMI with any of the other major pathogens. Multilevel models for all major pathogens were also fit without SCC parameters but no substantial differences in effect estimations were identified. This may be due to the low number of NIMI with these pathogens and the lack of statistical power associated with such low numbers. Interestingly, when risk ratios were analyzed for the coliforms individually, the presence of CNS in samples from postcalving cows did reveal a statistically significant risk for new E. coli infections (data not shown). It is possible that fresh cows with CNS infections might be more susceptible to infections with $E$. coli during this period of decreased immunity.

No significant associations between Corynebacterium spp. in either of the 2 previous samples before the NIMI with any of the major pathogens were identified (Tables 1 and 2). Among published observational studies, 38 analyses exist of the relationship between Corynebacterium spp. IMI and the occurrence of major pathogen NIMI: 22 of these identified a protective effect (although only 18 significantly), 13 associated Corynebacterium spp. IMI with an increased risk of major pathogen NIMI (7 significantly), and 2 found no effect. Green et al. (2002) found the timing of $\mathrm{Co}$ rynebacterium spp. infection to be relevant-quarters infected at dry-off showed a trend for increased occurrence of clinical mastitis, whereas quarters infected 1 wk precalving or postcalving had decreased likelihood of clinical mastitis occurrence. Zadoks et al. (2001) also showed significance in the interaction between Corynebacterium spp. IMI and herd as well as DIM and teat-end callosity. Although these authors identified Corynebacterium spp. to be protective overall against NIMI with Staph. aureus, an increased risk was seen in midlactation (61-120 DIM) as well as with rough teat ends. It may be that the effect of Corynebacterium spp. on NIMI is complicated and depends on several factors (Green et al., 2002).

\section{Susceptibility}

The susceptibility parameters presented here provide some interesting results. All of the statistically significant susceptibility parameters included in the multilevel logistic models were represented best by quadratic relationships. On the cow level, it is not surprising that cows with greater susceptibility to IMI would be more at risk of developing NIMI. This was a nonsignificant trend for Strep. uberis and was borderline significant for the coliforms, although no effect was seen for Staph. aureus or Strep. dysgalactiae (Table 2).

At the quarter level, the graphs for Staph. aureus and Strep. uberis differ from the graph for Strep. dysgalactiae. Initially, as quarter level susceptibility increases, the OR of a quarter acquiring a NIMI with Staph. aureus and Strep. uberis also increases. At a proportion of infected quarters of approximately 0.3 , however, the OR of a quarter acquiring a NIMI with either of these major pathogens began to decrease, although the susceptibility parameter was always associated with an increased risk of acquiring a major pathogen NIMI. As the proportion of infected quarters increased past 0.5 , some protective effect seemed to be seen for these 2 pathogens, although the data were very sparse and confidence intervals were extremely wide. A possible explanation for this is that false negatives for minor pathogens did occur (Se for CNS in single samples as defined here was only $56 \%$, whereas that for Corynebacterium spp. was 78\%; Dohoo et al., 2011b), and that IMI in the previous sample were simply not found and, therefore, not accounted for in modeling the risk for NIMI. The susceptibility parameters, then, might in fact be providing a more complete picture of the effects of minor pathogens than the modeling of the presence of the pathogens themselves.

The graph for OR of a NIMI with Strep. dysgalactiae is more straightforward: the more susceptible a quarter, the more likely it is to acquire a NIMI with this pathogen. Again, because some IMI might have been missed, it is possible that the behavior of the susceptibility parameter here may be more relevant than the indications provided by the presence of the minor pathogens in the previous samplings. 
The susceptibility parameters in this work were included to account for several unmeasured confounders not previously addressed in most of the previous literature. Any number of herd-level, cow-level, and quarter-level confounders (e.g., dirty environment, innate immunity, and poor teat-end conformation) should be accounted for by these parameters. It is interesting to note that the majority of infections comprising the susceptibility parameters were minor pathogen infections $(80.7 \%)$, and that these parameters were significantly related to the outcome (NIMI with a major pathogen) at the quarter level for all major pathogens. Alternatively, the presence of a minor pathogen directly before the NIMI occurred was never found to be significantly associated with the outcome, and was only statistically significant for the presence of CNS 2 samplings before a Staph. aureus NIMI (Table 2). Perhaps, as has been suggested by Green et al. (2002), the timing of the minor pathogen infection is important to determine its effect on quarter susceptibility.

\section{Other Considerations}

A trend was observed for samples taken every 3 wk to be less likely to be cultured with a major pathogen NIMI than samples taken 1 wk apart. This was observed with statistical significance only for the coliforms during the winter of 2007 and 2008 samplings. Because coliform infections are most often transient, it may be expected that they would be cultured less often when a longer period of time elapsed between samplings.

In the data used for these analyses, no speciation of CNS or Corynebacterium spp. occurred, which may have limitations. Several types of CNS are found in bovine milk, causing a wide range of chronicity and inflammatory effects in the mammary gland (Supré et al., 2011). Speciation of a subset $(n=1,400)$ of the CNS-positive samples included here has been completed, and 20 different species of CNS were identified. Staphylococcus chromogenes, Staphylococcus xylosus, and Staphylococcus simulans were found to account for $>75 \%$ of CNS IMI in this subset (Middleton et al., 2010). Coryneform bacteria also consist of several different species and strains. Due to the differing actions of these pathogens, grouping them together at the genus level, as is commonly done, may obscure some of their true activity. For instance, if some species are highly protective in the mammary gland, their effect would be decreased when less-protective species of the same genus were considered along with them. Hence, it would be ideal to be able to use speciated CNS and Corynebacterium spp. samples in the analyses of these data (Supré et al., 2011).

\section{CONCLUSIONS}

This quantitative analysis of a large data set such as this can stand together with previous work to reveal more about the interactions between major and minor pathogens in the bovine udder. Even with this extensive data set, however, there were not a large number of major pathogen NIMI and, therefore, not enough power to make a definitive statement about the effect of a minor pathogen infection on the acquisition of a major pathogen infection. Definitively answering questions of this nature would seem to require an extremely large data set dedicated especially to minor pathogen presence and detection of NIMI with major pathogens.

\section{ACKNOWLEDGMENTS}

Special thanks to Jonathan Smith, who helped with data preparation, and Henrik Stryhn, who assisted with theoretical development of the models (both of Centre for Veterinary Epidemiological Research, University of Prince Edward Island, Charlottetown, Canada). This work would not have been possible without the other organizers of the Canadian Bovine Mastitis Research Network's (St-Hyacinthe, QC, Canada) data collection platform, the National Cohort of Dairy Farms: Herman Barkema, Luc Des Côteaux, Trevor DeVries, Simon Dufour, and Jean-Philippe Roy. This research was financed by the Natural Science and Engineering Research Council (NSERC, Ottawa, ON, Canada); Alberta Milk (Edmonton, AB, Canada); Dairy Farmers of New Brunswick (Sussex, New Brunswick, Canada), Nova Scotia (Lower Truro, Nova Scotia, Canada), Ontario (Mississauga, ON, Canada), and Prince Edward Island (Charlottetown, PE, Canada); Novalait Inc. (Quebec City, QC, Canada); Dairy Farmers of Canada (Ottawa, ON, Canada); Canadian Dairy Network (Guelph, ON, Canada); Agriculture and Agri-Food Canada (Ottawa, ON, Canada); Public Health Agency of Canada (Ottawa, ON, Canada); Technology PEI Inc. (Charlottetown, PE, Canada); Université de Montréal (Montréal, QC, Canada); and the University of Prince Edward Island (Charlottetown, PE, Canada), through the Canadian Bovine Mastitis Research Network. Personal support comes from the Atlantic Veterinary College's DVM Graduate Program Award (Charlottetown, PE, Canada) and Natural Sciences and Engineering Research Council of Canada (NSERC, Ottawa, ON, Canada) Canada Graduate Scholarship.

\section{REFERENCES}

Andersen, S., I. R. Dohoo, R. Olde Riekerink, and H. Stryhn., and Mastitis Research Workers' Conference. 2010. Diagnosing intramammary infections: Evaluating expert opinions on the definition 
of intramammary infection using conjoint analysis. J. Dairy Sci. 93:2966-2975.

Beaudeau, F., H. Seegers, C. Fourichon, and P. Hortet. 1998. Association between milk somatic cell counts up to 400,000 cells/ml and clinical mastitis in French Holstein cows. Vet. Rec. 143:685-687.

Berry, E. A., and J. E. Hillerton. 2002. The effect of selective dry cow treatment on new intramammary infections. J. Dairy Sci. $85: 112-121$.

Compton, C. W. R., C. Heuer, K. Parker, and S. McDougall. 2007. Epidemiology of mastitis in pasture-grazed peripartum dairy heifers and its effects on productivity. J. Dairy Sci. 90:4157-4170.

Deluyker, H. A., J. M. Gay, and L. D. Weaver. 1993. Interrelationships of somatic cell count, mastitis and milk yield in a low somatic cell count herd. J. Dairy Sci. 76:3445-3452.

Djabri, B., N. Bareille, F. Beaudeau, and H. Seegers. 2002. Quarter milk somatic cell count in infected dairy cows: A meta-analysis. Vet. Res. 33:335-357.

Dohoo, I., S. Andersen, R. Dingwell, K. Hand, D. Kelton, K. Leslie, Y. Schukken, and S. Godden. 2011a. Diagnosing intramammary infections: Comparison of multiple versus single quarter milk samples for the identification of intramammary infections in lactating dairy cows. J. Dairy Sci. 94:5515-5522.

Dohoo, I. R., S. W. Martin, and H. Stryhn. 2009. Interpretation of variance parameters. Pages 583-585 in Veterinary Epidemiologic Research. 2nd ed. VER Inc., Charlottetown, PEI, Canada.

Dohoo, I. R., A. H. Meek, and S. W. Martin. 1984. Somatic cell counts in bovine milk: Relationship to production and clinical episodes of mastitis. Can. J. Comp. Med. 48:130-135.

Dohoo, I. R., J. Smith, S. Andersen, D. F. Kelton, and S. Godden. 2011b. Diagnosing intramammary infections: Evaluations based on a single milk sample. J. Dairy Sci. 94:250-261.

Erskine, R. J., and R. J. Eberhart. 1988. Comparison of duplicate and single quarter milk samples for the identification of intramammary infections. J. Dairy Sci. 71:854-856.

Forbes, D. 1970. The pathogenic significance of various intramammary infections. Br. Vet. J. 126:260-267.

Green, L. E., Y. H. Schukken, and M. J. Green. 2006. On distinguishing cause and consequence: do high somatic cell counts lead to lower milk yield or does high milk yield lead to lower somatic cell count? Prev. Vet. Med. 76:74-89.

Green, M. J., L. E. Green, G. F. Medley, Y. H. Schukken, and A. J. Bradley. 2002. Influence on dry period bacterial intramammary infection on clinical mastitis in dairy cows. J. Dairy Sci. 85:25892599 .

Hogan, J. S., R. N. Gonzalez, S. C. Harmon, S. P. Nickerson, J. W. Oliver, J. W. Pankey, and K. L. Smith. 1999. Laboratory Handbook on Bovine Mastitis. 1st ed. National Mastitis Council, Madison, WI.

Lam, T. J. G. M., Y. H. Schukken, J. H. van Vliet, F. J. Grommers, M. J. M. Tielen, and A. Brand. 1997. Effect of natural infection with minor pathogens on susceptibility to natural infection with major pathogens in the bovine mammary gland. Am. J. Vet. Res. $58: 17-22$.

Matthews, K. R., R. J. Harmon, and B. E. Langlois. 1991. Effect of naturally-occurring coagulase negative staphylococci infections on new infections by mastitis pathogens in the bovine. J. Dairy Sci. 74:1855-1859.

Middleton, J. R., J. Perry, D. T. Scholl, S. Dufour, I. R. Dohoo, C. Calloway, and S. Andersen. 2010. Relationship between coagulasenegative staphylococcal species and mammary quarter milk so- matic cell count on North American dairy farms. Page 22 in Proc. of Seminar on Coagulase-Negative Staphylococci in the Bovine, Ghent, Belgium. Universiteit Gent, Ghent, Belgium.

Parker, K. I., C. Compton, F. M. Anniss, A. Weir, C. Heuer, and S. McDougall. 2007. Subclinical and clinical mastitis in heifers following the use of a teat sealant precalving. J. Dairy Sci. 90:207-218.

Piepers, S., G. Opsomer, H. W. Barkema, A. de Kruif, and S. De Vliegher. 2010. Heifers infected with coagulase-negative staphylococci in early lactation have fewer cases of clinical mastitis and a higher milk production in their first lactation than non-infected heifers. J. Dairy Sci. 93:2014-2024.

Piepers, S., K. Peeters, G. Opsomer, H. W. Barkema, K. Frankena, and S. De Vliegher. 2011. Pathogen group specific risk factors at herd, heifer and quarter levels for intramammary infections in early lactating dairy heifers. Prev. Vet. Med. 99:91-101.

Postle, D. S., M. Roguinsky, and B. Poutrel. 1978. Induced staphylococcal infections in the bovine mammary gland. Am. J. Vet. Res. 39:29-35.

Pyörälä, S., and S. Taponen. 2009. Coagulase-negative staphylococciEmerging mastitis pathogens. Vet. Microbiol. 134:3-8.

Rainard, P., and B. Poutrel. 1988. Effect of naturally occurring intramammary infections by minor pathogens on new infections by major pathogens in cattle. Am. J. Vet. Res. 49:327-329.

Reyher, K. K., S. Dufour, H. W. Barkema, L. Des Côteaux, T. J. DeVries, I. R. Dohoo, G. P. Keefe, J.-P. Roy, and D. T. Scholl. 2011. The National Cohort of Dairy Farms - A data collection platform for mastitis research in Canada. J. Dairy Sci. 94:16161626

Rupp, R., F. Beaudeau, and D. Boichard. 2000. Relationship between milk somatic cell counts in the first lactation and clinical mastitis occurrence in the second lactation of French Holstein cows. Prev. Vet. Med. 46:99-111.

Rupp, R., and D. Boichard. 2000. Relationship of early first lactation somatic cell count with risk of subsequent first clinical mastitis. Livest. Prod. Sci. 62:169-180.

Schukken, Y. H., R. N. González, L. L. Tikofsky, H. F. Schulte, C. G. Santisteban, F. L. Welcome, G. J. Bennett, M. J. Zurakowski, and R. N. Zadoks. 2009. CNS mastitis: Nothing to worry about? Vet. Microbiol. 134:9-14

Schukken, Y. H., K. E. Leslie, D. A. Barnum, B. A. Mallard, J. H. Lumsden, P. C. Dick, G. H. Vessie, and M. E. Kehrli. 1999. Experimental Staphylococcus aureus intramammary challenge in late lactation dairy cows: Quarter and cow effects determining the probability of infection. J. Dairy Sci. 82:2393-2401.

Schukken, Y. H., D. Van de Geer, F. J. Grommers, J. A. H. Smit, and A. Brand. 1989. Intramammary infections and risk factors for clinical mastitis in herds with low somatic cell counts in bulk milk. Vet. Rec. 125:393-396.

Supré, K., F. Haesebrouck, R. N. Zadoks, M. Vaneechoutte, S. Piepers, and S. De Vliegher. Some coagulase-negative Staphylococcus species affect udder health more than others. 2011. J. Dairy Sci. 94: $2329-2340$.

Whist, A. C., and O. Østerås. 2007. Associations between somatic cell counts at calving or prior to drying-off and clinical mastitis in the remaining or subsequent lactation. J. Dairy Res. 74:66-73.

Zadoks, R. N., H. G. Allore, H. W. Barkema, O. C. Sampimon, G. J Wellenberg, Y. T. Grohn, and Y. H. Schukken. 2001. Cow- and quarter-level risk factors for Streptococcus uberis and Staphylococcus aureus mastitis. J. Dairy Sci. 84:2649-2663. 